\title{
The exploitation of obsidian in the Central Plateau of Santa Cruz, Argentina: Results from La María and Cerro Tres Tetas and a regional perspective
}

\author{
Manuel E. Cueto ${ }^{1}$, Ariel D. Frank ${ }^{2}$, Fabiana Skarbun ${ }^{3}$ \\ 1. Consejo Nacional de Investigaciones Científicas y Técnicas (CONICET), Argentina. \\ Email: Cueto: manuelcueto@fcnym.unlp.edu.ar; Franck: frank.ariel@gmail.com; \\ Skarbun: fskarbun@fcnym.unlp.edu.ar \\ 2. División Científica de Arqueología, Facultad de Ciencias Naturales y Museo, Universidad Nacional de La \\ Plata (UNLP). La Plata, Buenos Aires, Argentina.
}

\begin{abstract}
:
La María and Cerro Tres Tetas archaeological localities are located in the Central Plateau, in the province of Santa Cruz, Argentine Patagonia. This area presents abundant lithic raw materials of very good quality for knapping including flint, chalcedony and silicified wood. These raw materials were used by the inhabitants of the region since the end of the Pleistocene until recent historical times. Besides, we have recorded the exploitation of exotic stones in low proportions at the archaeological sites. Among these, the most abundant is obsidian which probably comes from sources located more than $125 \mathrm{~km}$ away. In this context, the use of this type of raw material should be evaluated in terms of social and symbolic issues.

In this paper, we examine the strategies of acquisition and reduction of the obsidian found at the archaeological sites Cerro Tres Tetas 1, Casa del Minero 1, Cueva de La Ventana, La Mesada and Cueva Túnel. We carry out a technomorphological analysis of the obsidian remains from these sites.

Results from this work strengthen the idea that the groups which lived in the Central Plateau knew about and exploited an obsidian source known as Pampa del Asador. A raise in the use of this raw material throughout time is recorded, reaching its peak in the late Holocene. We identified two different moments in the exploitation of obsidian at the regional level. During the final Pleistocene and early Holocene, obsidian would not have played a relevant role in the organization of technology. Production sequences indicate that tools probably were entered to the sites already manufactured. During the middle and late Holocene nodules and cores could have been brought into the sites. The strategies involved in their reduction are in broad terms similar to those implemented with local raw materials; there is no evidence that obsidian had more value in any way. On the other hand, it is also not possible to state that there was just an eventual exploitation of this raw material. We believe that obsidian was acquired during mobility circuits which enabled the contact between different groups.
\end{abstract}

Keywords: obsidian; exploitation; technological analysis; Patagonia; Argentina

Published by the School of History, Classics and Archaeology, University of Edinburgh ISSN: 2055-0472. URL: http://journals.ed.ac.uk/lithicstudies/

This work is licensed under a Creative Commons Attribution 2.5 UK: Scotland License. 


\section{Introduction}

Raw materials of very good quality for knapping are ubiquitous in the Mid-Southern part of the Central Plateau of Santa Cruz, Argentina (See Figure 1) There are varieties of flint, silicified wood, silicified tuff and chalcedony; quarries are located mainly in the Chön Aike Formation and, in a lesser extent, in the Baqueró Formation and in Holocene deposits (Panza 1994; Paunero et al. 2005; Skarbun 2015).

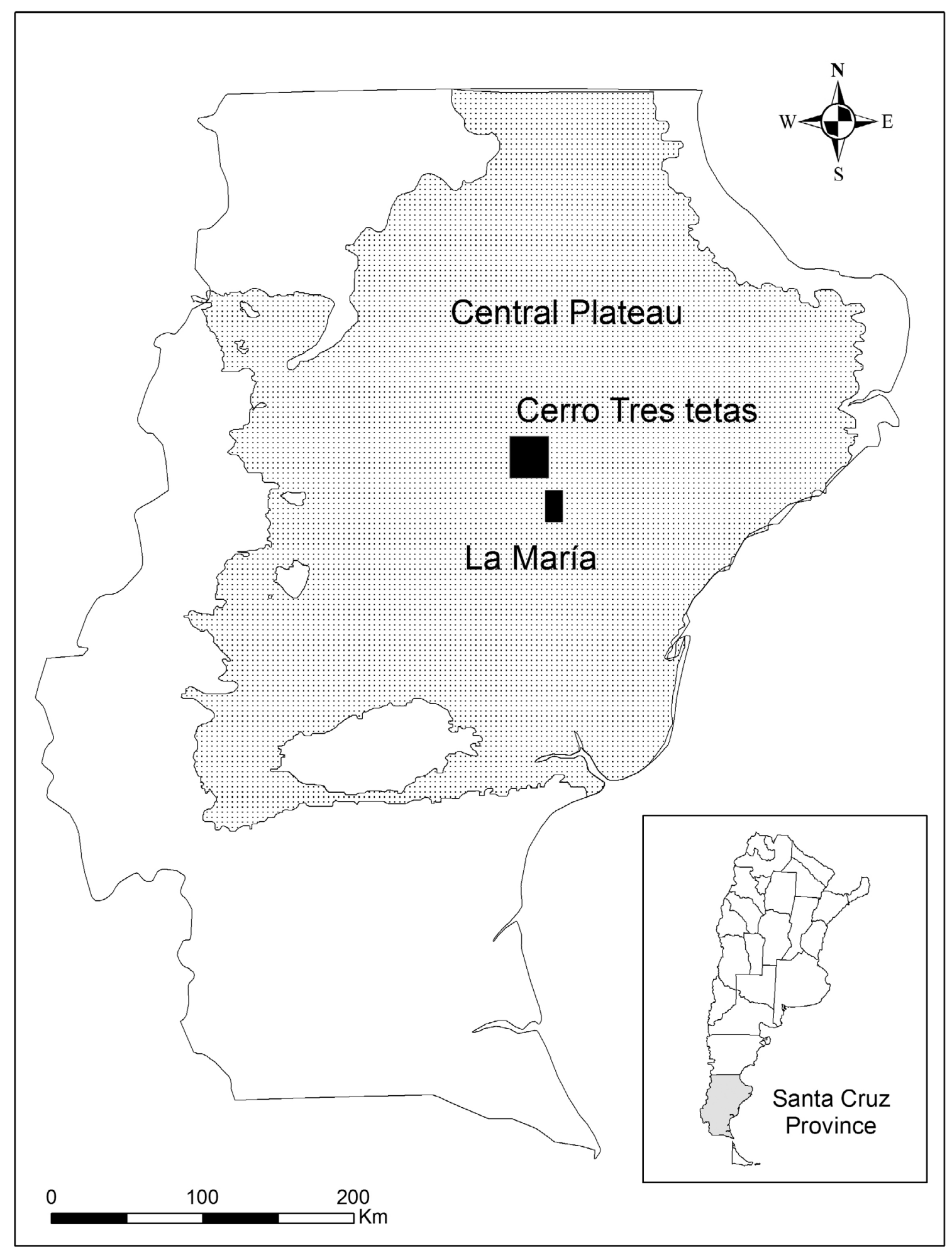

Figure 1. Location of the Central Plateau and La María and Cerro Tres Tetas archaeological localities. 
During the research performed in this part of the plateau, in the archaeological localities La María and Cerro Tres Tetas, we have recorded that all the sites have nearby quarries (Skarbun 2015), which were used recurrently by the people of the region since the end of the Pleistocene until recent historical times. Generally, the technological strategies implemented with these raw materials show a spatial differentiation of manufacture tasks. The preparation of cores and the production of blanks were performed mainly at the quarries while the rest of the activities were developed at sheltered sites (Frank et al. 2015). Most tools were made of flint and were knapped in an expeditive way. Hence, this strategy is part of the social practices in which the distribution and availability of lithics played an important role (Skarbun 2011: 207).

At the same time, at the analyzed archaeological sites we have recorded the exploitation of allochthonous rocks, although in a low degree. One of them is the obsidian which comes from sources located more than $125 \mathrm{~km}$ away from the area. In this context of great availability of resources, the use of a non-local raw material should be evaluated in terms of social and symbolic issues such as mobility, intergroup communication, and the exchange, transportation and conservation of this raw material.

In this paper, we examine the strategies of acquisition, exploitation and consumption of the obsidian artifacts found at these localities. We perform a techno-morphological analysis of obsidian remains from sites in La María archaeological locality: Casa del Minero 1 (CDM1), Cueva de La Ventana (LV), La Mesada (LM) and Cueva Túnel (CT) as well as in Cerro Tres Tetas 1 (C3T1) site from Cerro Tres Tetas archaeological locality. In this way, we will be able to understand how this raw material circulated, the strategies adopted in production sequences, the work invested in the manufacture and in the design of the tools.

The identified patterns will be contextualized taking into consideration the reduction strategies applied on local rocks and the available information about the management of obsidian in neighbour areas. By doing this, we will contribute to current discussions regarding the exploitation of obsidian in Patagonia.

\subsection{Obsidian in Southern Patagonia}

In Southern Patagonia (south of $46^{\circ} \mathrm{S}$ ), three types of obsidian have been identified up to the moment. They belong to the sources Pampa del Asador, Cordillera Baguales and Seno Otway (Stern 2004). These sources are thought to be located on the west and, in two cases, well to the south (See Figure 2). Obsidian from these sources can be distinguished on a macroscopic level (by their color) as well as by its geochemical characteristics (Fernández \& Leal 2014; Stern 1999; Stern \& Franco 2000; Stern et al. 1995; Stern \& Prieto 1991; Stern 2004).

Most of the obsidian remains found in Southern Patagonia come from Pampa del Asador (Espinosa \& Goñi 1999; Stern 2004). It is a secondary source; raw material from this type of obsidian spreads through an availability area of $c a .2000 \mathrm{~km}^{2}$ (calculation based on Figure 2 from Belardi et al. 2006). The primary source either does not exist anymore or it has not been found yet. The raw material from Pampa del Asador was used on a macroregional scale, being found up to $850 \mathrm{~km}$ to the NE (Gómez Otero \& Stern 2005). The nearest point of the natural availability area to our research region is the alluvial fan (Belardi et al. 2006), located at a distance which ranges between 125 and $149.6 \mathrm{~km}$ to the west of the analyzed sites. It is black or translucent gray and occasionally has brown veins (Fernández et al. 2015). It is found as pebbles which are usually between 3 and $6 \mathrm{~cm}$ long and have a weathered surface and a dull vesicular cortex (Belardi et al. 2006). It usually has a homogenous texture, although sometimes it can hold plagioclase crystals (Stern 2004). Belardi and others (2006) identified 
six varieties and sub-varieties by neutron activation analysis of trace elements. Towards the borders of the source, its size and roundness diminish.

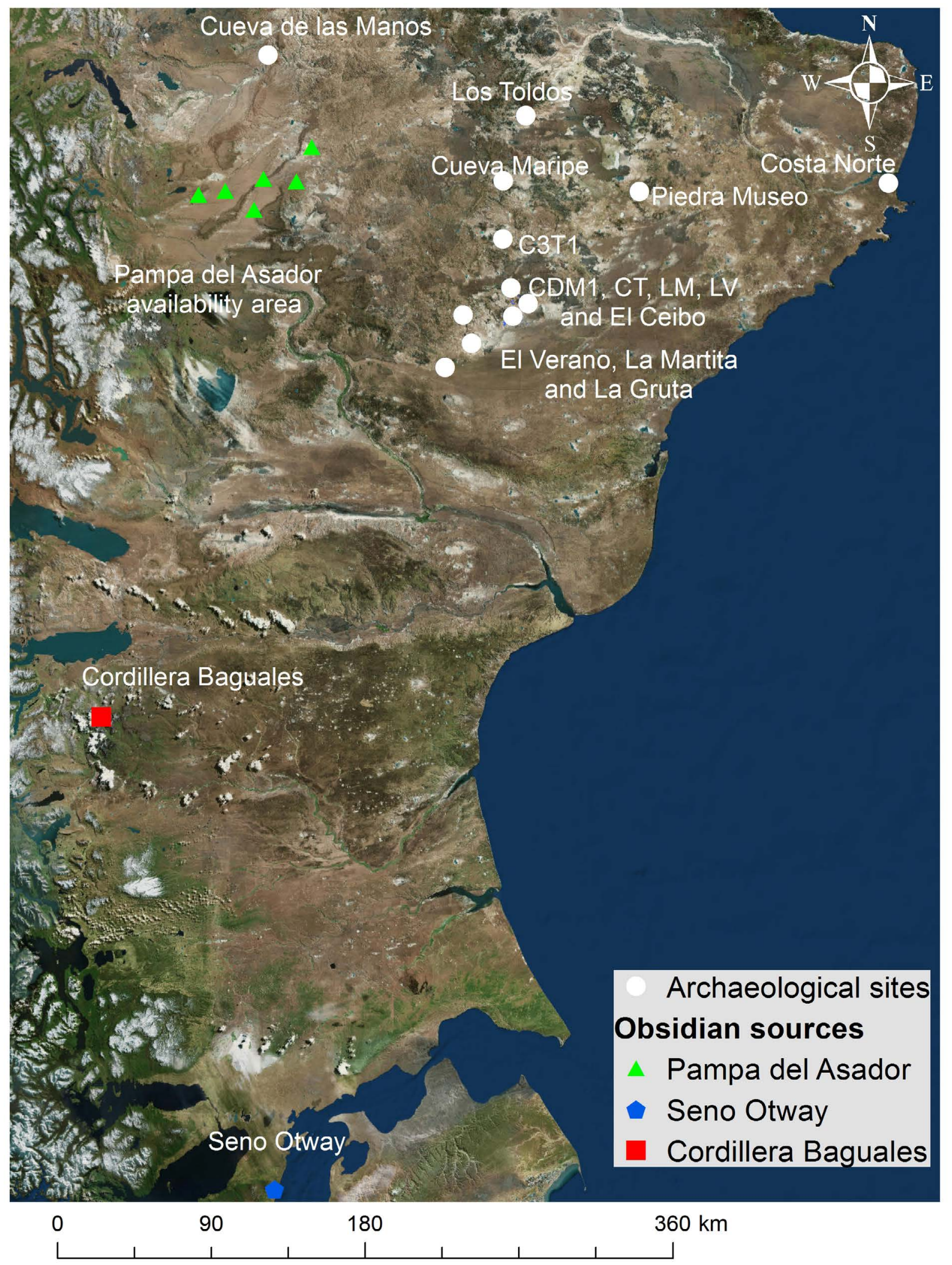

Figure. 2. Localization of the sources and sites with obsidian in the Central Plateau. 
The identification of the obsidian from Cordillera Baguales and Seno Otway types was achieved through the analysis of archaeological remains. The exact location of these sources is up to the moment unknown. Their approximate position has been inferred based on some of its geochemical characteristics, their geological ages, and by taking into consideration the area in which archaeological remains of these obsidian types are more usually found (See Figure 2) (Stern \& Franco 2000; Stern \& Prieto 1991).

Source known as Cordillera Baguales is supposed to be located approximately $340 \mathrm{~km}$ to the Southwest of the analyzed sites. Archaeological remains of this obsidian type are found near Lago Argentino and are much less usual in other sectors. Its color is banded gray to greenish (Stern 2004); sometimes it has potassium feldspar crystals (Fernández \& Leal 2014). According to Franco, the characteristics of the recovered samples imply that this type of obsidian occurs naturally in veins (Franco pers. comm. in Fernández and Leal 2014).

Seno Otway Type was identified through the analysis of archaeological remains from coastal sites near the Otway Sea. The probable location of the source is about $525 \mathrm{~km}$ to the Southwest of the sites analyzed in this paper. It is thought that the source might not be accessible by land. The color of the artifacts is usually dark green or gray, sometimes it has a banded texture. The primary source would be individual fragments of breccias (Fernández \& Leal 2014; San Román \& Prieto 2004; Stern \& Prieto 1991).

\subsection{Obsidian use patterns in the Central Plateau}

Research on other stratigraphic sites from the Central Plateau shows that obsidian was exploited since the first occupation of the region (See Figure 2). The geochemical analyses made up to date indicate that it comes from Pampa del Asador (read a synthesis in GarcíaHerbst et al. 2007). Very few remains were recovered from final Pleistocene sites (12000 10000 years ${ }^{14} \mathrm{C}$ BP). Obsidian was only recorded in Cerro Tres Tetas 1 (10 small flakes) (Paunero 1993-94; 2003) and La Gruta 1 (3 artifacts) (Franco et al. 2010). Cardich and Flegenheimer state that in level 11 of Los Toldos 3 there are obsidian flakes but do not present any other information (Cardich \& Flegenheimer 1978). A current review of this assemblage showed that there are four obsidian flakes (Del Piccolo et al. 2015: 5).

During the early Holocene (10000-7500 years ${ }^{14} \mathrm{C}$ BP) in the Central Plateau, the amount, variety and size of obsidian artifacts seem to increase. Among tools, un-stemmed projectile points dominate the assemblages, e.g., a bifacial sub-triangular point from Los Toldos 3 (Aguerre 2003; Cardich \& Flegenheimer 1978; Cardich et al. 1981-82; Durán et al. 2003; Hermo \& Miotti 2010). According to Hermo \& Miotti (2010), the use of obsidian as "materia prima para la confección casi exclusiva de puntas de proyectil tendría mayor ligazón con las formas de apropiación y circulación de las rocas y de los bienes de alto contenido simbólico, que con necesidades estrictamente técnicas” (Hermo \& Miotti 2010: 117). These authors state that obsidian points were brought to the area by exchange.

The use of obsidian seems to increase in the middle Holocene (7500-3500 years $\left.{ }^{14} \mathrm{C} \mathrm{BP}\right)$. Obsidian remains were found in almost every site from this period (Cardich et al. 1993-1994; Crivelli Montero 1976-1980; Durán 1987; Franco et al. 2015; Hermo 2008: 96-111). The techno-morphological characteristics of the debitage show an increase in blade production. At the same time, these traits indicate that core reduction tasks and the final shaping of tools were performed at the sites, while decortication and core rejuvenation activities were scarce. Few obsidian tools were found. Most are unifacial tools made on blades and, in a lesser extent, bifacial ones. These tools include scrapers, retouched flakes and blades, and notches with bifacial retouch. Natural edges of blades were probably also used. Pyramidal irregular cores, with flake and blade scars, were found. These had some cortex but had small sizes and were practically exhausted (Crivelli Montero 1976-1980; Hermo 2008: 431-438; Hermo \& 
Miotti 2010). Hermo \& Miotti (2010) state that the technical procedures used in the Central Plateau for the manufacture of blades are the same in obsidian and in local rocks. However, they remark some differences in the operational chaine on this raw material, when compared to local resources, such as its acquisition, the use of un-retouched natural edges and the smaller (and less variable) size of blades (Hermo \& Miotti 2010:121). During the late Holocene (3500-200 years $\left.{ }^{14} \mathrm{C} \mathrm{BP}\right)$, there is greater artifact variability. Obsidian assemblages include blades (with a standardized size and un-retouched edges), as well as projectile points and scrapers (Durán 1987; Hermo \& Miotti 2010).

At the sites located in the northern part of the Atlantic coast in Santa Cruz, to the east of the Central Plateau (See Figure 2 - Costa Norte), the proportion of obsidian artifacts ranges between $0.88 \%$ and $4.26 \%$. Remains show that final shaping tasks were not frequently performed. Intermediate steps prevail and initial knapping activities are also frequent. Although more than $60 \%$ of the flakes are internal, $20 \%$ of the remains have cortex (resembling the one in pebbles). The cortex in some cases covers the whole dorsal face. For example, in Alero El Oriental site all the flakes are external. The remains are usually very small (5.1 to $20 \mathrm{~mm}$ ). No tools were found and only one very small core with residuary cortex was recovered from the lowest component of Alero El Oriental (Ambrústolo et al. 2012). Based on this evidence, these authors proposed that obsidian was transported to the coast as pebbles or as cores which were acquired either by direct access to the sources or by exchange with other groups in the area (Ambrústolo et al. 2012).

At the same time, Hermo \& Miotti (2010) suggest that in the middle and in the late Holocene, obsidian pebbles were brought to the Central Plateau. Following the ideas presented by Feblot-Augustins \& Perles (1992), Hermo and Miotti consider that pebbles could be regarded as "highly valued goods" which had aesthetic and social significance. On the contrary, Pallo \& Borrero (2015: 297), based on the low proportion of obsidian in the archaeological record, reject the idea that the groups that inhabited areas distant to the source (such as the Central Plateau) acquired this raw material by exchange. They suggest that obsidian entered the region as "transportes modelables como riders acompañando a visitantes". They define visits as "el movimiento de gente sin el propósito específico de realizar intercambio -participar en cacerías, controlar recursos u otras actividades-” (Pallo \& Borrero 2015:299).This would create an eventual deposition of these materials far away from the sources.

\section{Materials and methods}

We carried out the analysis of the obsidian remains from the following sites and components: Final Pleistocene: C3T1 Level 5; Early Holocene: CDM1 Level 3 Middle, LV Level 6, LM Level 8; Middle Holocene: C3T1 Level 4, CDM1 Level 3 Superior, LV Level 4 and 5; Late Holocene: CDM1 Level 1 and 2 (See Table 1). All of these sites are multistratigraphic and are located in caves or rock shelters (Cueto 2015: 98-113; Frank 2011: 60-84; Paunero 2000; Skarbun 2011: 86-88). Chronology was established by radiocarbon dates in some of the components. In other components their stratigraphic location, as well as some diagnostic characteristics of the assemblages, were taken into consideration.

We made a macroscopic identification of the raw material and distinguished obsidian from other lithologies based on its diagnostic traits (colour, brightness, transparency, texture, inclusions, cortex, and grain size). Every assemblage was classified in an integrative and flexible way. Morphological, technical and functional attributes were taken into consideration, since the results from our experimental and functional studies affect our technomorphological classification. This is due to the fact that, from our point of view, the production process is a complex procedure which is guided by the specific function of the 
produced tool, as well as the broader activities in which it is going to be used. This approach contemplates the organization of the society which uses the tools and the characteristics of the landscape in which these tasks are developed (Cueto 2015: 12-14; Cueto et al. 2014; Frank 2011: 19; Skarbun 2011: 28-33).

Table 1.14C dates of analyzed components. Abbreviations: n.d. - not dated.

\begin{tabular}{|c|c|c|c|c|}
\hline Period & Site & Level & Date & References \\
\hline Late Holocene & CDM1 & 1 and 2 & n.d. & \\
\hline \multirow{5}{*}{$\begin{array}{l}\text { Middle } \\
\text { Holocene }\end{array}$} & LV & 4 and 5 & n.d. & \\
\hline & CDM1 & 3 Superior & LP-1552: $5.190 \pm 80$ years ${ }^{14} \mathrm{C} B P$ & $\begin{array}{l}\text { (Paunero et al. } \\
\text { 2007b) }\end{array}$ \\
\hline & LM & $5 b$ & Beta $-135964: 4.500 \pm 40$ years ${ }^{14} \mathrm{C}$ BP & (Paunero 2000) \\
\hline & & 6 & n.d. & \\
\hline & C3T1 & 4 & LP-538: $5220 \pm 70$ years ${ }^{14} \mathrm{C} \mathrm{BP}$ & $\begin{array}{l}\text { (Paunero et al. } \\
\text { 2007a) }\end{array}$ \\
\hline \multirow{3}{*}{$\begin{array}{l}\text { Early } \\
\text { Holocene }\end{array}$} & LM & 8 & Beta $-135963: 9.090 \pm 40$ years ${ }^{14} \mathrm{C}$ BP & Paunero 2000) \\
\hline & LV & 6 & $\begin{array}{l}\text { Beta }-135965: 7.970 \pm 40 \text { years }{ }^{14} \mathrm{C} \text { BP } \\
\text { AA-35237: } 7.665 \pm 75 \text { years }{ }^{14} \mathrm{C} B P\end{array}$ & (Paunero 2000) \\
\hline & CDM1 & 3 Medium & n.d. & \\
\hline \multirow[t]{4}{*}{ Pleistocene } & CT & $\begin{array}{l}\text { Component } \\
\text { inferior }\end{array}$ & $\begin{array}{l}\text { AA-71148: } 10.400 \pm 100 \text { years }{ }^{14} \mathrm{C} B P \\
\text { AA-71147: } 10.408 \pm 59 \text { years }{ }^{14} \mathrm{C} \text { BP } \\
\text { LP-1965 10.420 } \pm 180 \text { years }{ }^{14} \mathrm{C} \text { BP } \\
\text { AA-82496: } 10.510 \pm 100 \text { years }{ }^{14} \mathrm{C} \text { BP }\end{array}$ & $\begin{array}{l}\text { (Frank 2011: 75; } \\
\text { Paunero et al. } \\
\text { 2015) }\end{array}$ \\
\hline & C3T1 & 5 & 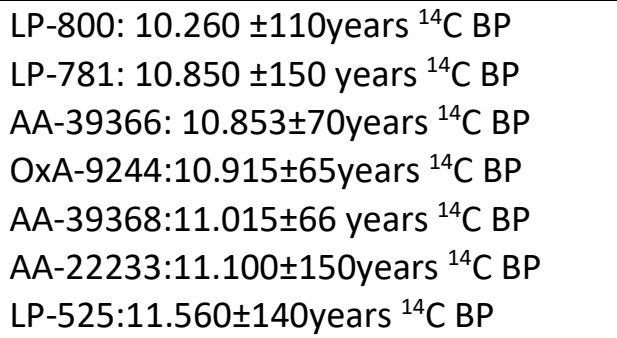 & $\begin{array}{l}\text { (Paunero \& } \\
\text { Castro 2001) }\end{array}$ \\
\hline & CDM1 & 3 inferior & AA-45705: $10.250 \pm 110$ years ${ }^{14} \mathrm{C}$ BP & $\begin{array}{l}\text { Paunero et al. } \\
\text { 2007b) }\end{array}$ \\
\hline & & 4 & $\begin{array}{l}\text { AA-37208: } 10.967 \pm 55 \text { years }{ }^{14} \mathrm{C} \text { BP } \\
\text { AA-37207: } 10.999 \pm 55 \text { years }{ }^{14} \mathrm{C} \text { BP }\end{array}$ & $\begin{array}{l}\text { Paunero et al. } \\
\text { 2007b) }\end{array}$ \\
\hline
\end{tabular}

The technological analysis involved the determination of the stage of reduction to which the obsidian remains from the different sites belong. Debitage and tools were studied, as both groups provide specific information about different stages of the production sequence and about the state in which the raw material entered the site. This approach enables the organization of the artifacts according to the following technical steps: 1 . Core Preparation and initial reduction (Decortication), 2. Core reduction and blank production, and 3. Final shaping of tools (reflaking, retouch, bifacial thinning) (Cueto 2015: 35-38; Frank 2011: 9-20; Paunero 1993-94; Skarbun 2011: 27-37 and bibliography cited). When possible, percussion and pressure techniques were recorded (Apel 2008; Pelegrin 2006). The traits taken into consideration are: presence and amount of cortex, size of the artifacts, type of platform, type of bulb, type of flakes and type of blanks used for tools. As Level 4 from C3T1 is still under analysis, we only took into consideration the frequency of artifacts and the characteristics of tools for this assemblage. 
After the analysis of the artifacts, we compared the results with the trends observed on local raw materials in the area. Similarities and differences were identified; they are useful for the discussion of the social significance of these stones. We also compared the results with the information about obsidian remains from other sites from the Central Plateau. This way, we will be able to understand obsidian exploitation as part of the general strategies of production and consumption implemented by past local societies.

\section{Results}

The analyzed sample consists of 366 obsidian artifacts. Most of them are black, some are slightly translucid, have brown veins or phenocrystals. There are also gray obsidian remains. From the four final Pleistocene components taken into account, only 10 remains were recovered ( $0.33 \%$ of the lithics from this period). The proportion of obsidian during the early Holocene raises to $0.82 \%$ ( $n=5$; three analyzed components), while for the middle Holocene this raw material represents $2.64 \%(n=114)$ of the four considered occupations. Finally, in the only late Holocene component frequencies and proportions are higher, as $9.27 \%(n=236)$ of the remains are made in obsidian (See Table 2). Hence, we can see a progressive raise in the proportion of obsidian remains in the assemblages throughout time, as a consequence of its exploitation (See Figure 3). It is worth highlighting that all the Holocene assemblages have obsidian remains, but for the final Pleistocene, evidence from this stone comes only from unit 5 of C3T1.

Table 2. Absolute frequency and proportion of obsidian in the analyzed assemblages. Abbreviations: $\mathrm{n}$ asmb. total number of artifacts in the assemblage; $n$ obs. - total number of obsidian artifacts in the assemblage. Empty cells - the site was not occupied during that period or that the lithic assemblage has not been analyzed yet.

\begin{tabular}{|c|c|c|c|c|c|c|c|c|c|c|c|c|}
\hline \multirow[b]{2}{*}{ Site } & \multicolumn{3}{|c|}{ Final Pleistocene } & \multicolumn{3}{|c|}{ Early Holocene } & \multicolumn{3}{|c|}{ Middle Holocene } & \multicolumn{3}{|c|}{ Late Holocene } \\
\hline & $\begin{array}{c}n \\
\text { asmb. }\end{array}$ & $\begin{array}{c}n \\
\text { obs. }\end{array}$ & $\begin{array}{c}\% \\
\text { obs. }\end{array}$ & $\begin{array}{c}n \\
\text { asmb. }\end{array}$ & $\begin{array}{c}n \\
\text { obs. }\end{array}$ & $\begin{array}{c}\% \\
\text { obs. }\end{array}$ & $\begin{array}{c}n \\
\text { asmb. }\end{array}$ & $\begin{array}{c}n \\
\text { obs. }\end{array}$ & $\begin{array}{c}\% \\
\text { obs. }\end{array}$ & $\begin{array}{c}n \\
\text { asmb. }\end{array}$ & $\begin{array}{c}n \\
\text { obs. }\end{array}$ & $\begin{array}{c}\% \\
\text { obs. }\end{array}$ \\
\hline \multirow[t]{2}{*}{ CDM1 } & 1240 & 0 & 0 & \multirow[t]{2}{*}{539} & \multirow[t]{2}{*}{3} & \multirow[t]{2}{*}{0.56} & \multirow[t]{2}{*}{454} & \multirow[t]{2}{*}{27} & \multirow[t]{2}{*}{5.95} & \multirow[t]{2}{*}{2547} & \multirow[t]{2}{*}{236} & \multirow[t]{2}{*}{9.27} \\
\hline & 1200 & 0 & 0 & & & & & & & & & \\
\hline LV & & & & 34 & 1 & 2.94 & 57 & 4 & 7.02 & & & \\
\hline LM & & & & 38 & 1 & 2.63 & 2109 & 33 & 1.56 & & & \\
\hline CT & 113 & 0 & 0 & & & & & & & & & \\
\hline C3T1 & 514 & 10 & 1.95 & & & & 1729 & 51 & 2.95 & & & \\
\hline Total & 3067 & 10 & 0.33 & 611 & 5 & 0.82 & 4349 & 115 & 2.64 & 2547 & 236 & 9.27 \\
\hline
\end{tabular}

\section{Percent}

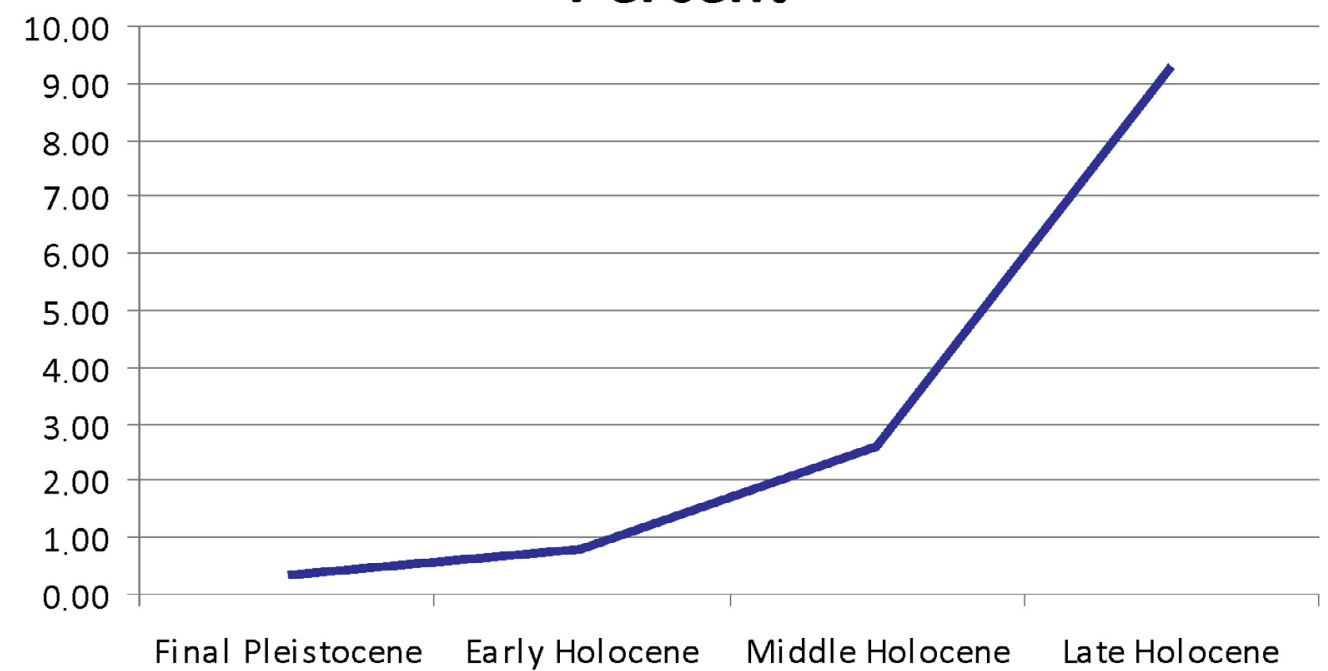

Figure 3. Relative percentage of obsidian remains throughout time. 
In all the obsidian assemblages debitage prevails (See Figure 4). There are scarce tools (only in the final periods of the Holocene) and cores are absent (See Table 3). Two tools have been recovered corresponding to the middle Holocene: a sidescraper and a retouched blade. Two bifacial projectiles points, an end scraper-point and a retouched flake (both unifacial) have been found in late Holocene contexts (See Figure 5). With regards to completeness, there is parity in each time period between the proportion of remains which have a percussion platform and those which lack of it (See Table 4).

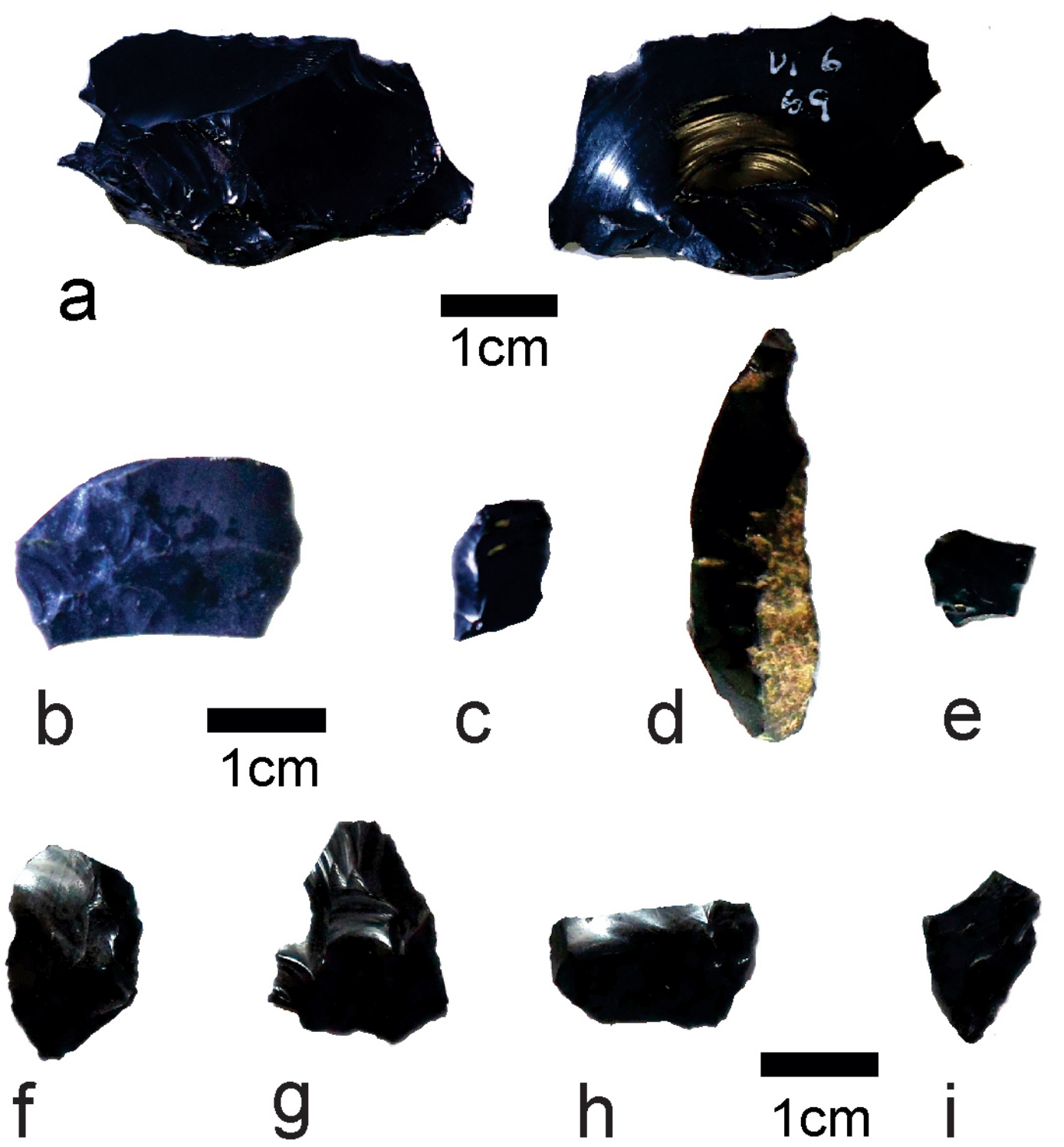

Figure 4. Sample of debitage. Early Holocene: a. core reduction flake, LV. Middle Holocene: b and d. Core reduction flakes from LV and LM respectively; c and e. Final shaping flakes from LV and LM respectively. Late Holocene: f, g, i. Final shaping debris (f. bifacial thinning flake), h. Core reduction flake.

Production sequences show null (final Pleistocene and Early Holocene) and low (middle and late Holocene) amounts of remains generated during decortication. In each period, there are usually medium amounts of flakes produced during the reduction of cores and a high proportion of products from the final shaping of tools (See Table 5). This would indicate that at habitation sites the last stages of manufacture were performed. Percussion and pressure techniques were recorded. The latter is clear for the middle and late Holocene in the final stages of formatization of tools. It is interesting that bipolar flaking is almost completely 
absent; it was identified in only one artifact from the middle Holocene. Most flakes from the Holocene do not have cortex. Very few flakes have more than $50 \%$ of cortex on the dorsal face (See Table 6 and Figure 6). Among tools, only one retouched flake from the late Holocene has scarce cortex.

Table 3. Structure of the assemblag es from each period.

\begin{tabular}{lcccccc}
\hline Period & $\mathbf{n}$ Tools & \% Tools & n Debitage & \% Debitage & n Total & \% Total \\
\hline Final Pleistocene & 0 & 0 & 10 & 100 & 10 & 100 \\
Early Holocene & 0 & 0 & 5 & 100 & 5 & 100 \\
Middle Holocene & 2 & 1.74 & 113 & 98.26 & 115 & 100 \\
Late Holocene & 4 & 1.69 & 232 & 98.31 & 236 & 100 \\
\hline Total & $\mathbf{6}$ & $\mathbf{1 . 6 4}$ & $\mathbf{3 6 0}$ & $\mathbf{9 8 . 3 6}$ & $\mathbf{3 6 6}$ & $\mathbf{1 0 0}$ \\
\hline
\end{tabular}

a

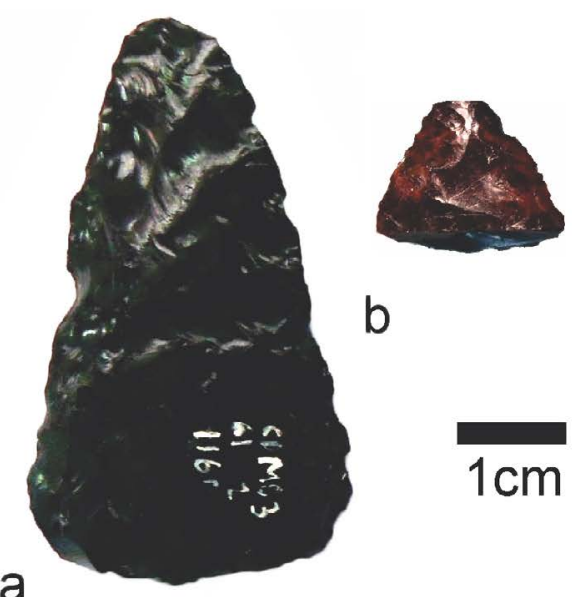

Figure 5. Lithic tools. Late Holocene, CDM1. a. bifacial projectile point, b. fragment of bifacial projectile point, c. end scraper-point, d. retouched flake.

Table 4. Proportion of flakes with platform.

\begin{tabular}{lccccc}
\multicolumn{1}{c}{ Completeness } & $\begin{array}{c}\text { Final } \\
\text { Pleistocene }\end{array}$ & $\begin{array}{c}\text { Early } \\
\text { Holocene }\end{array}$ & $\begin{array}{c}\text { Middle } \\
\text { Holocene }\end{array}$ & $\begin{array}{c}\text { Late } \\
\text { Holocene }\end{array}$ & Total \\
\hline $\begin{array}{l}\text { Complete and proximal } \\
\text { fragments }\end{array}$ & $2,39 \%$ & $0,96 \%$ & $32,54 \%$ & $64,11 \%$ & $100 \%$ \\
Distal fragments & $3,23 \%$ & $1,94 \%$ & $29,03 \%$ & $65,81 \%$ & $100 \%$ \\
\hline Total & $\mathbf{2 , 7 5 \%}$ & $\mathbf{1 , 3 7 \%}$ & $\mathbf{3 1 , 0 4 \%}$ & $\mathbf{6 4 , 8 4 \%}$ & $\mathbf{1 0 0 \%}$ \\
\hline
\end{tabular}

Table 5. Frequency of artifacts according to reduction stage.

\begin{tabular}{lllllllll}
\hline & \multicolumn{2}{l}{ Final Pleistocene } & \multicolumn{2}{c}{ Early Holocene } & \multicolumn{2}{c}{ Middle Holocene } & \multicolumn{2}{c}{ Late Holocene } \\
Production stages & $\mathbf{n}$ & $\mathbf{\%}$ & $\mathbf{n}$ & $\mathbf{\%}$ & $\mathbf{n}$ & $\mathbf{\%}$ & $\mathbf{n}$ & $\%$ \\
\hline Decortication & 0 & 0 & 0 & 0 & 3 & 3.03 & 3 & 1.49 \\
Core reduction & 1 & 12.50 & 2 & 50 & 40 & 40.40 & 66 & 32.67 \\
Final shaping & 7 & 87.50 & 2 & 50 & 56 & 56.57 & 133 & 65.84 \\
Total & 8 & 100 & 4 & 100 & 99 & 100 & 202 & 100 \\
\hline
\end{tabular}

Only retouch and microretouch flakes (among those produced during the final shaping of tools) were identified for the final Pleistocene and the early Holocene. This kind of debitage is also the most abundant for the other periods, but in these we also recognized reflaking and 
some bifacial thinning debris (See Figure 7). On the other hand, six flakes corresponding to the middle Holocene and four from the late Holocene show that there was resharpening of edges, indicating that at the sites the maintenance of the tools was performed.

Table 6. Amount of cortex in flakes from each occupation period.

\begin{tabular}{llll}
\hline Cortex & Early Holocene & Middle Holocene & Late Holocene \\
\hline None (0\%) & $80 \%$ & $75.23 \%$ & $91.56 \%$ \\
Very scarce (1-24\%) & $0 \%$ & $13.76 \%$ & $3.11 \%$ \\
Scarce (25-49\%) & $20 \%$ & $6.42 \%$ & $3.11 \%$ \\
Partial (50-74\%) & $0 \%$ & $0.92 \%$ & $0.44 \%$ \\
Abundant (75-99\%) & $0 \%$ & $2.75 \%$ & $1.33 \%$ \\
Very abundant (100\%) & $0 \%$ & $0.92 \%$ & $0.44 \%$ \\
Total & $100 \%$ & $100 \%$ & $100 \%$ \\
\hline
\end{tabular}
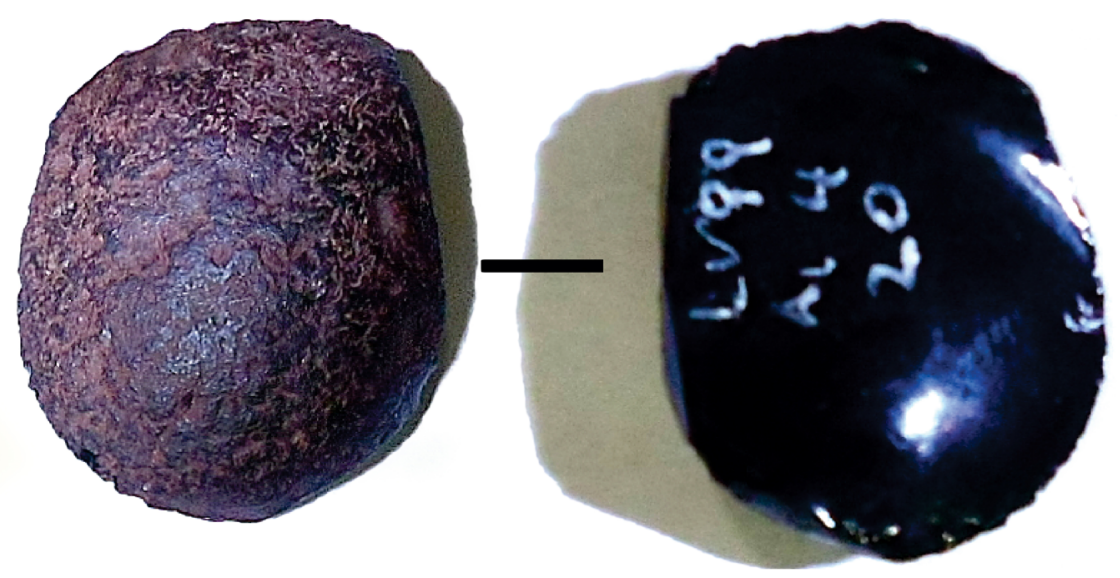

a

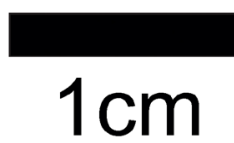

b

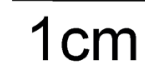

Figure 6. Mid Holocene flakes with residuary cortex. a. Decortication flake, LV. b. Core reduction flake, LM.

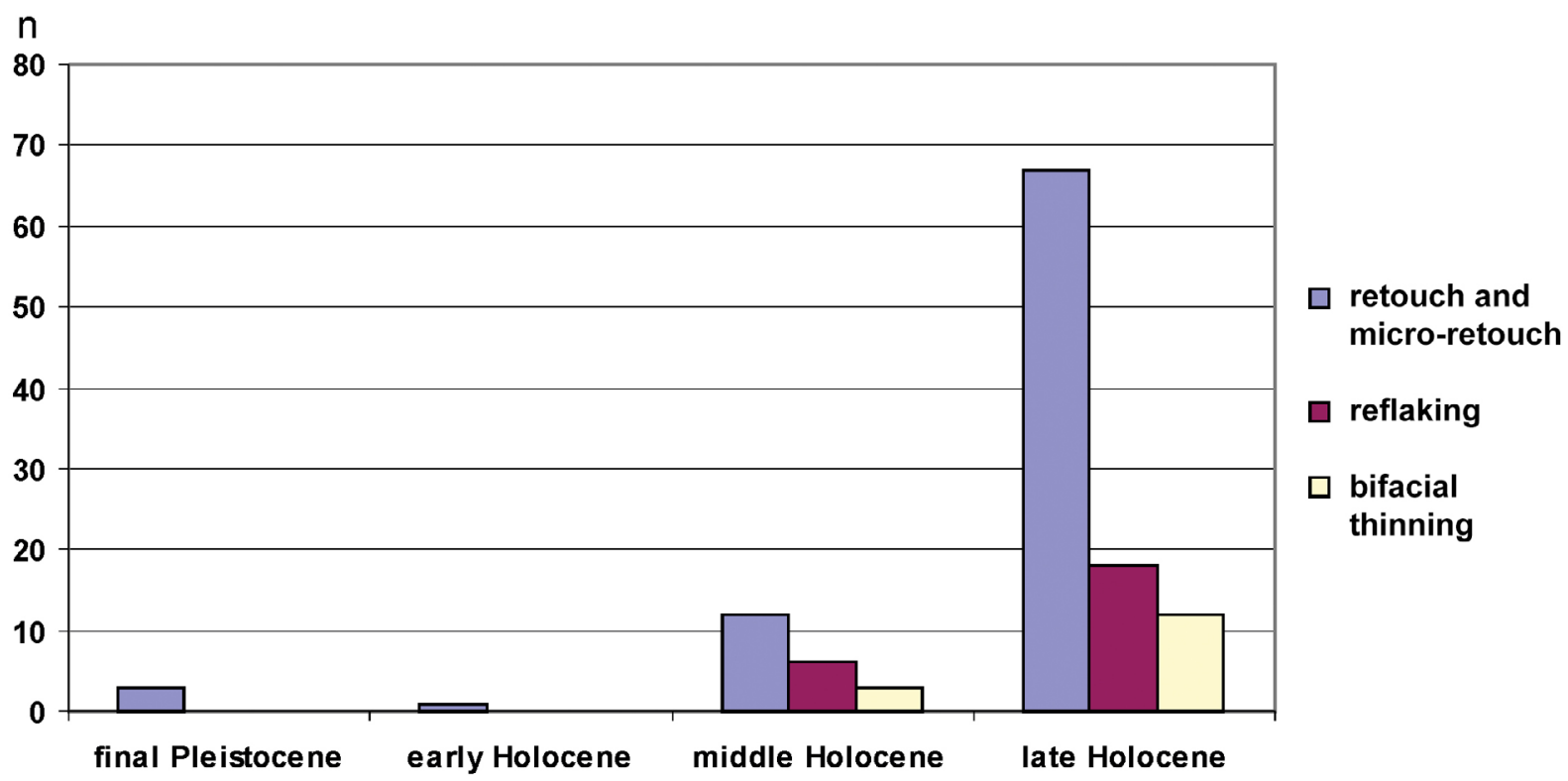

Figure 7. Amount of flakes produced during the final shaping of tools in each period. 
In each period and in each stage of production flakes were produced (See Table 7). In the middle and late Holocene low amounts of bladelets and blades, and a very low number of long flakes, were manufactured during the reduction of cores. Finally, for these periods we would like to highlight the high proportion of bladelets generated during the final trimming of tools.

Table 7. Proportion of flake classes in each stage of production.

\begin{tabular}{lllllll}
\hline Period & Production stages & Flakes & Bladelets & Long flakes & Blades & Total \\
\hline Final & Core reduction & $100 \%$ & $0 \%$ & $0 \%$ & $0 \%$ & $100 \%$ \\
Pleistocene & Final shaping & $100 \%$ & $0 \%$ & $0 \%$ & $0 \%$ & $100 \%$ \\
Early & Core reduction & $100 \%$ & $0 \%$ & $0 \%$ & $0 \%$ & $100 \%$ \\
Holocene & Final shaping & $50 \%$ & $50 \%$ & $0 \%$ & $0 \%$ & $100 \%$ \\
Middle Holocene & Decortication & $100 \%$ & $0 \%$ & $0 \%$ & $0 \%$ & $100 \%$ \\
& Core reduction & $83.87 \%$ & $6.45 \%$ & $3.23 \%$ & $6.45 \%$ & $100 \%$ \\
\multirow{2}{*}{ Late } & Final shaping & $78.26 \%$ & $21.74 \%$ & $0 \%$ & $0 \%$ & $100 \%$ \\
Holocene & Decortication & $100 \%$ & $0 \%$ & $0 \%$ & $0 \%$ & $100 \%$ \\
& Core reduction & $92.42 \%$ & $3.03 \%$ & $1.52 \%$ & $3.03 \%$ & $100 \%$ \\
& Final shaping & $87.22 \%$ & $12.03 \%$ & $0.75 \%$ & $0 \%$ & $100 \%$ \\
\hline
\end{tabular}

The size of complete flakes ranges between small $(0.1-2 \mathrm{~cm})$ and very small $(2.1-4 \mathrm{~cm})$. There is only one medium (4.1-6 cm) sized remain in the late Holocene. Most of the very small flakes in the middle and late Holocene were made during the final trimming of tools. For the other stages, the size of flakes fluctuates between small and very small (See Table 8).

Table 8. Size of complete flakes for each production stage and occupation period.

\begin{tabular}{|c|c|c|c|c|c|c|c|c|c|}
\hline \multirow{2}{*}{$\begin{array}{l}\text { Period } \\
\text { Final Pleistocene }\end{array}$} & \multirow{2}{*}{$\begin{array}{c}\text { Production stages } \\
\text { Final shaping }\end{array}$} & \multicolumn{2}{|c|}{$\begin{array}{l}\text { Very small } \\
(0.1-2 \mathrm{~cm})\end{array}$} & \multicolumn{2}{|c|}{$\begin{array}{c}\text { Small } \\
(2.1-4 \mathrm{~cm})\end{array}$} & \multicolumn{2}{|c|}{\begin{tabular}{|c|} 
Medium \\
$(4.1-6 \mathrm{~cm})$
\end{tabular}} & \multicolumn{2}{|c|}{ Total } \\
\hline & & 1 & $33.33 \%$ & 2 & $66.67 \%$ & 0 & $0 \%$ & 3 & $100 \%$ \\
\hline \multirow[t]{2}{*}{ Early Holocene } & Core reduction & 0 & $0 \%$ & 1 & $100 \%$ & 0 & $0 \%$ & 1 & $100 \%$ \\
\hline & Final shaping & 1 & $100 \%$ & 0 & $0 \%$ & 0 & $0 \%$ & 1 & $100 \%$ \\
\hline \multirow[t]{3}{*}{ Middle Holocene } & Decortication & 0 & $0 \%$ & 2 & $100 \%$ & 0 & $0 \%$ & 2 & $100 \%$ \\
\hline & Core reduction & 8 & $53.33 \%$ & 7 & $46.67 \%$ & 0 & $0 \%$ & 15 & $100 \%$ \\
\hline & Final shaping & 39 & $97.50 \%$ & 1 & $2.50 \%$ & 0 & $0 \%$ & 40 & $100 \%$ \\
\hline \multirow[t]{4}{*}{ Late Holocene } & Decortication & 1 & $100 \%$ & 0 & $0 \%$ & 0 & $0 \%$ & 1 & $100 \%$ \\
\hline & Core reduction & 9 & $60.00 \%$ & 5 & $33.33 \%$ & 1 & $6.67 \%$ & 15 & $100 \%$ \\
\hline & Final shaping & 74 & $98.67 \%$ & 1 & $1.33 \%$ & 0 & $0 \%$ & 75 & $100 \%$ \\
\hline & Undetermined & 4 & $100 \%$ & 0 & $0 \%$ & 0 & $0 \%$ & 4 & $100 \%$ \\
\hline
\end{tabular}

There are very few flakes with platform in the final Pleistocene and early Holocene assemblages. Dihedral platforms predominate in the first period while prepared and punctiform platforms dominate the following moment. Data for the middle and late Holocene is interesting, especially with regards to the final shaping of tools; in both periods punctiform and lineal platforms are prevalent (See Table 9).

\section{Discussion and conclusions}

Results from our investigation strengthen the idea presented by other researchers (Ambrústolo et al. 2012; Franco et al. 2015; García-Herbst et al. 2007; Hermo \& Miotti 2010; Paunero 1993-94; Paunero et al. 2005) that societies that lived in the Central Plateau of Santa 
Cruz knew and exploited the source Pampa del Asador since the beginning of the regional peopling. From our point of view, Pampa del Aasdor is the probable source of the obsidian found at the sites because the macroscopic characteristics of the recovered remains (color, crystals, cortex, size) are similar to the traits of the obsidian from this source. At the same time, the color of the remains does not resemble the raw material from Cerro Baguales nor Seno Otway, which is usually green or gray with veins. As Pampa del Asador is the nearest of the obsidian sources it is also more likely that it was incorporated to the mobility circuits of the societies that inhabited the Central Plateau. Alternatively, the acquisition of the raw material could have been performed by the development of communication networks with groups which inhabited other areas near the source, which probably had a direct access to it. Geochemical analyses are currently being performed. They will determine the provenance of the raw material.

Table 9. Proportion of percussion platforms for each production stage and period of occupation. Abbreviations: Dihed. - Dihedral; Fac. - faceted; Cort. - Cortical; Prep. - prepared; Punct. - punctiform.

\begin{tabular}{|c|c|c|c|c|c|c|c|c|c|}
\hline Period & Production stages & Dihed. & Fac. & Lineal & Flat & Cort. & Prep. & Punct. & Total \\
\hline \multirow[t]{2}{*}{ Final Pleistocene } & Core reduction & $100 \%$ & $0 \%$ & $0 \%$ & $0 \%$ & $0 \%$ & $0 \%$ & $0 \%$ & $100 \%$ \\
\hline & Final trimming & $50 \%$ & $25 \%$ & $0 \%$ & $25 \%$ & $0 \%$ & $0 \%$ & $0 \%$ & $100 \%$ \\
\hline \multirow[t]{2}{*}{ Early Holocene } & Core reduction & $0 \%$ & $0 \%$ & $0 \%$ & $0 \%$ & $0 \%$ & $100 \%$ & $0 \%$ & $100 \%$ \\
\hline & Final trimming & $0 \%$ & $0 \%$ & $0 \%$ & $0 \%$ & $0 \%$ & $0 \%$ & $100 \%$ & $100 \%$ \\
\hline \multirow[t]{3}{*}{ Middle Holocene } & Decortication & $0 \%$ & $0 \%$ & $0 \%$ & $50 \%$ & $0 \%$ & $0 \%$ & $50 \%$ & $100 \%$ \\
\hline & Core reduction & $10.53 \%$ & $21.05 \%$ & $5.26 \%$ & $47.3 \% 7$ & $0 \%$ & $5.26 \%$ & $10.53 \%$ & $100 \%$ \\
\hline & Final trimming & $9.3 \%$ & $9.3 \%$ & $25.58 \%$ & $6.98 \%$ & 2.335 & $4.65 \%$ & $41.86 \%$ & $100 \%$ \\
\hline \multirow[t]{3}{*}{ Late Holocene } & Decortication & $0 \%$ & $0 \%$ & $100 \%$ & $0 \%$ & $0 \%$ & $0 \%$ & $0 \%$ & $100 \%$ \\
\hline & Core reduction & $19.23 \%$ & $15.38 \%$ & $15.38 \%$ & $23.08 \%$ & $0 \%$ & $15.38 \%$ & $611.54 \%$ & $100 \%$ \\
\hline & Final trimming & $6.19 \%$ & $11.34 \%$ & $29.9 \%$ & $13.40 \%$ & $1.0 \% 3$ & $5.15 \%$ & $32.99 \%$ & 100\% \\
\hline
\end{tabular}

The analyzed sample shows a progressive raise in the exploitation of obsidian throughout time. During the final Pleistocene, evidence comes only from Unit 5 of C3T1, which is one of four components dated for this period. Obsidian is more recurrent during the early and middle Holocene, as all the assemblages have this kind of raw material. Finally, during the late Holocene, obsidian increases dramatically. Only one archaeological component from this period has been analyzed so far. If obsidian proportions are also high in other late occupations, then it is probable that the exploitation of obsidian during this period was more frequent. In this sense, the late Holocene occupation from C3T1 is currently under study.

Evidence for the exploitation of obsidian during the final Pleistocene and the early Holocene is scarce in our sites (in the rest of the Central Plateau there seems to be slightly higher amounts of obsidian remains during the early Holocene) (Aguerre 2003; Cardich \& Flegenheimer 1978; Durán et al. 2003; Franco et al. 2010). Hence, it seems that this raw material did not play an important role in the technological organization of the societies. Assemblages are dominated by small and very small flakes, most of them produced during the final shaping of tools. This might be indicating that tools either finished or in the last stages of their manufacture were brought to the sites. This pattern coincides with what has been observed regionally: the finding of obsidian projectile points (Aguerre 2003; Cardich \& Flegenheimer 1978; Hermo \& Miotti 2010) which would have been acquired by exchange and brought to the sites already made (Hermo \& Miotti 2010). Our studies in the area show that the preparation of cores and the production of blanks in local raw materials were performed mainly at the quarries while the final stages of tool manufacture were performed at sheltered sites (Cueto 2015: 187, 191; Frank 2011: 67-85; Paunero \& Castro 2001; Skarbun 
2011: 207-208; Skarbun \& Frank 2011). With regards to obsidian, it is necessary to examine if this pattern corresponds to the fact that tools were brought already manufactured from the source area or if, instead, this is evidence of a local structuration of space. If the latter was the case, then nodules or cores could have been brought to these localities which were then knapped in different spaces before being entered to caves and rock-shelters were the final stages of tool production took place.

In the middle Holocene, even though obsidian remains in the analyzed sites are still scarce, they are slightly more abundant than in previous periods, showing that it was more exploited. This coincides with regional observations (Crivelli Montero 1976-1980; Hermo 2008: 89-120, 444; Hermo \& Miotti 2010). It takes place in a context which has been associated by certain authors with a demographic raise and other social changes (Hermo 2008: 110; Miotti 2006) and which in general shows more intensive lithic production. Therefore, we can begin to define some trends in order to discuss the way in which the raw material was brought to the Central Plateau and how it was exploited.

Production sequences at the habitation sites from Middle Holocene are characterized by the development of the final stages but also include some decortication tasks. This is similar to what has been identified regionally (Crivelli Montero 1976-1980; Hermo 2008: 89-120; Hermo \& Miotti 2010). There is more cortex in the obsidian remains from the Middle Holocene than in the debitage from the other periods. This might be showing that some nodules or cores with cortex were brought to the sites. If we take into consideration the fact that the size of decortication and core reduction debitage is small and very small, then it is possible to state that the stones taken to the sites were small or, at the most, medium-sized. During the production of blanks a significant amount of blade-like artifacts (blades, bladelets and long flakes) were knapped. The presence of this type of debitage is not an isolated phenomenon. Similar trends have been observed for the production of blanks in several raw materials in the region (Castro 1994: 237-256; Crivelli Montero 1976-1980; Durán 1987; Hermo 2008: 316, 404-408, 417; Paunero et al. 2007a, among others). Only the scarce evidence of bipolar percussion seems to differentiate the production of obsidian from the trends recorded for local lithologies.

The final stages of manufacture in obsidian included mainly the marginal shaping of edges, but also in a lesser extent reflaking and bifacial thinning, which would involve more work. Therefore, the pattern of edge shaping is similar to the one identified for local raw materials for the same sites in terms of work investment and technical procedures (Frank 2015; Iparraguirre \& Cueto 2015; Paunero et al. 2007a; Skarbun 2009; 2011). In turn, the abundance of bladelets among the final shaping products, together with the high proportion of punctiform and lineal platforms, could be an indication of a more intensive use of pressure in obsidian that in local raw materials for this last stage (local resources show very few bladelets and abundance of flat platforms) (see Skarbun 2011: 108-188). Finally, there is evidence indicating that edge resharpening was performed with this raw material, as well as with local resources.

Two obsidian tools were recovered from two of the four analyzed occupations. During this time period the frequency of tools made with local raw materials and discarded at the sites clearly exceeds those found for previous moments. In this context, we consider that the amount of obsidian tools found is low. Probably, tools made or resharpened at the sites were discarded in or taken to other spaces. On the other hand, according to Hermo \& Miotti (2010) some debitage without secondary shaping could be actually used artifacts; these authors believe that this would be a distinctive trait of this raw material. However, we must note that this treatment, if it actually took place, is not an exclusive characteristic of obsidian. On the contrary it is a feature shared with local resources. According to functional analysis natural edges from blades and flakes were used in many sites such as unit 4 from C3T1 and the 
contemporary occupation from site Cueva 13 from Los Toldos (Castro 1994: 299-307; Paunero et al. 2007a).

As we stated before, during the late Holocene there is a greater amount of obsidian in the assemblage. The great amount of debitage without cortex supports the idea that scarce decortication activities took place at the sites. However, and similarly to the previous period, there is evidence that, at least some obsidian nodules or cores with cortex were brought to the area. The majority of the obsidian stones brought to the area must have been small. However, there is at least one complete flake and a bifacial point of medium size. This means that medium-sized or bigger elements were transported sometimes. In this sense, there are some similarities with the assemblages from Costa Norte. For instance, in Costa Norte a very small core with cortex was found and most of the flakes were small (Ambrústolo et al. 2012).

Most of the manufacture activities performed with obsidian relate to the production of blanks and the final shaping of tools. In Costa Norte, neighbour to the Central Plateau, on the contrary, blank production and decortication dominate and as a consequence there is a higher amount of cortex in the remains (Ambrústolo et al. 2012). In CDM1, flakes were generated during the reduction of cores and the production of blanks. Blade-like debitage (blades, bladelets and long flakes) was also manufactured, but not as frequent as during the middle Holocene. This kind of remain decreased in 50\% when compared to the previous period. On the other hand, the different types of flakes have similar proportions when compared to local resources (Skarbun 2011: 108-188).

Tasks related to the marginal trimming of the edges predominated for the final shaping of the tools. However, as in the middle Holocene, there is also evidence of reflaking and bifacial thinning. This hints at the local production of the bifacial projectile points found at the site. Among these products, there are a series of bladelets and some other remains which have punctiform and lineal platforms which could indicate the use of pressure. These attributes are different to the ones identified in the case of local resources (Skarbun 2011: 108-188), implying there could have been a difference among raw materials with regards to the application of this technique. Some similarities can be observed between the local and regional patterns of obsidian exploitation. In particular, the production of blades, projectile points and end-scrapers is similar to what has been observed in other sites (Durán 1987; Hermo \& Miotti 2010). The fact that only two projectile points were found in CDM1 and that they were manufactured in obsidian could show that this raw material was preferred for this kind of tool. However, our surface records in both localities show abundant evidence of point production with local stones (Paunero et al. 2010; Paunero et al. 2011).

As a synthesis, results from our work show that the production activities developed with obsidian in the Mid-Southern part of the Central Plateau of Santa Cruz might differ throughout time. We propose the existence of two distinct moments. The first moment includes final Pleistocene and early Holocene occupations. In this moment there was a weak exploitation of this raw material. Obsidian did not have a significant role in the organization of technology and it is possible that tools were brought to the sites already manufactured.

The second moment begins during the middle Holocene. A trend towards the increase in the exploitation of this raw material is recorded, which is distinctive in the late Holocene. During this moment, the production strategies in obsidian are, in broad terms, similar to those implemented with local resources. It can therefore be interpreted that the management of obsidian was incorporated to the routine processes of tool manufacture, which involved socially shared knowledge and modes of production. Hence, there is no evidence which would allow us to infer that obsidian had a greater value than local rocks. On the other hand, although there is not an outstanding differential treatment of this raw material, the strategies adopted to acquire it are different to those used for local resources. The fact that obsidian artifacts in different localities from the Central Plateau are less abundant than those made in 
local stones does not rule out the possibility that this raw material could have been obtained by exchange nor the knowledge about its localization and flaking qualities. Production sequences for this second moment seem to be reasonably clear, so it does not seem plausible for us that it reached the area as a consequence of just its eventual management. In this sense, we believe it is possible that obsidian was acquired during the mobility circuits seasonally or annually developed, which could be linked to the exchange of other goods, the acquisition of different materials as well as to diverse kind of meetings which necessarily strengthen social bonds and the sense of belonging between groups.

\section{Acknowledgements}

We are grateful to Lic. Rafael Paunero, who directed the excavations and the research in La María and Cerro TresTetas. We are thankful to all the members of our research team, who have participated in the field work in which assemblages were collected. CONICET and UNLP funded this research.

\section{References}

Aguerre, A.M. 2003, La Martita: ocupaciones de 8000 años en la Cueva 4. In: Arqueología y Paleoambiente en la Patagonia Santacruceña Argentina (Aguerre, A.M., Ed.), Imprenta Nuevo Offset, Buenos Aires: p. 29-61. (in Spanish) ("The Martita: 8000 years of occupations in Cave 4”)

Ambrústolo, P., Zubimendi, M.A. \& Stern, C. 2012, Explotación de obsidiana negra en la costa norte de Santa Cruz (Patagonia argentina). Cazadores Recolectores del Cono Sur, 6: 77-86. (in Spanish) ("Exploitation of black obsidian on the north coast of Santa Cruz (Patagonia Argentina”)

Apel, A. 2008, Knowledge, Know-how and Raw Material - The Production of Late Neolithic Flint Daggers in Scandinavia. Journal of Archaeological Method and Theory, 15: 91111. doi:10.1007/s10816-007-9044-2

Belardi, J.B., Tiberi, P., Stern, R.C. \& Súnico, A. 2006, Al este del cerro Pampa: ampliación del área de disponibilidad de obsidiana de Pampa del Asador (Provincia de Santa Cruz). Intersecciones en Antropología 7: 27-36. (in Spanish) (“East of the Cerro Pampa: enlargement of the obsidian availability area from Pampa Del Asador (Santa Cruz Province)")

Cardich, A. \& Flegenheimer, N. 1978, Descripción y tipología de las industrias más antiguas de Los Toldos. Relaciones de la Sociedad Argentina de Antropología. Nueva Serie, 12: 225-242. (in Spanish) ("Description and typology of the oldest industries of Los Toldos”)

Cardich, A., Mansur-Franchomme, E., Durán, V. \& Giesso, M. 1982, Arqueología de las cuevas de El Ceibo, Provincia de Santa Cruz, Argentina. Relaciones de la Sociedad Argentina de Antropología 14(2): 241-267. (in Spanish) ("Archaeology in the caves of El Ceibo, Province of Santa Cruz, Argentina”)

Cardich, A., Paunero, R.S. \& Castro, A.S. 1994, Análisis de los conjuntos líticos de la cueva 2 de Los Toldos (Santa Cruz, Argentina). Anales del Instituto de la Patagonia. Serie Ciencias Humanas, 22: 149-173. (in Spanish) (“Analysis of Cave 2 lithic assemblages of Los Toldos (Santa Cruz, Argentina)”) 
Castro, A.S. 1994, El análisis funcional de materiales líticos por medio de la observación microscópica de huellas de uso: un modelo alternativo de clasificación tipológica. Tesis doctoral thesis at the Facultad de Ciencias Naturales y Museo, Universidad Nacional de La Plata, La Plata, 529 p. (in Spanish) ("Functional analysis of lithic materials through microscopic observation of traces of use: an alternative model of typological classification")

Crivelli Montero, E. 1980, La industria Casapedrense (Colección Menghin). Runa, 13(1-2): 35-57. (in Spanish) ("The Casapedrense industry (Collection Menghin)”)

Cueto, M.E. 2015, Análisis de los procesos de uso de artefactos líticos en sociedades cazadoras-recolectoras. Ocupaciones correspondientes a la transición Pleistoceno/Holoceno, Meseta Central de Santa Cruz. BAR International Series 2776. British Archaeological Reports Ltd., Oxford, 198 p. (in Spanish) ("Analysis of the processes of use lithic in hunter-gatherer societies. Occupations related to the Pleistocene/Holocene transition, Santa Cruz Central Plateau”)

Cueto, M.E., Skarbun, F. \& Frank, A.D. 2014, Tecnología lítica de los cazadores-recolectores de la meseta central patagónica. Balances y perspectivas para una propuesta de integración. In: Indústrias líticas na América do Sul: Abordagens teóricas e metodológicas (Lourdeau, A., Viana, S.A. \& Rodet, M.J., Eds.), Série Estudos Contemporâneos na Arqueologia Vol. 1, EdUFPE, Recife: p. 173-202. (in Spanish) ("Lithic technology of the hunter-gatheres from the patagonic central plateau. Balance and perspective for an integral proposal”)

Del Piccolo, D., Sibilio, S. \& Skarbun, F. (2015), Patrimonio y colecciones arqueológicas. Informe sobre el inventario de la colección lítica de Los Toldos. (unpublished). Informe. FCNyM, UNLP, La Plata, 10 p. (in Spanish) ("Heritage and archaeological collections. Inventory report of the lithic collection of Los Toldos”).

Durán, V. 1987, Estudio tecno-tipológico de los raspadores del sitio El Verano-Cueva 1. Patagonia Centro Meridional, Santa Cruz, Argentina. Anales de Arqueología y Etnología, 41-42: 129-163. (in Spanish) (“Techno-typological study of El VeranoCueva 1's scrapers")

Durán, V., Gil, A., Neme, G. \& Gasco, A. 2003, El Verano: ocupaciones de 8900 años en la Cueva 1 (Santa Cruz, Argentina). In: Arqueología y Paleoambiente en la Patagonia Santacruceña Argentina (Aguerre, A.M., Ed.), Imprenta Nuevo Offset, Buenos Aires: p. 93-120. (in Spanish) ("El Verano: 8900 occupations years in Cave 1 (Santa Cruz, Argentina”)

Espinosa, S.L. \& Goñi, R. 1999, ¡Viven!: una fuente de obsidiana en la provincia de Santa Cruz. In: Soplando en el viento... Actas de las Terceras Jornadas de Arqueología de la Patagonia (Goñi, R., Ed.), Instituto Nacional de Antropología y Pensamiento Latinoamericano y Universidad Nacional del Comahue, Neuquén-Buenos Aires: p. 177188. (in Spanish) (“Alive! An obsidian source in the province of Santa Cruz”)

Féblot-Augustins, J. \& Perles, C. 1992, Pespectives ethnoarchéologiques sur les échanges a longue distance. In: Ethonarchéologie: justification, problemes, limites (Audouze, F., Gallay, A. \& Roux, V., Eds.), APDCA, Juan-les-Pins: p. 195-209.

Fernández, M.V. \& Leal, P. 2014, Determining the Provenance of Obsidian in Southern Patagonia Using Optical Properties. Archaeometry, 56(1): 1-18. doi:10.1111/arcm.12059 
Fernández, M.V., Stern, C.R. \& Leal, P.R. 2015, Geochemical analysis of obsidian from archaeological sites in northwestern Santa Cruz Province, Argentine Patagonia. Quaternary International, 375: 44-54. doi:10.1016/j.quaint.2014.11.013

Franco, N.V., Cirigliano, N.A., Vetrisano, L. \& Ambrústolo, P. 2015, Raw material circulation at broad scales in southern Patagonia (Argentina): The cases of the Chico and Santa Cruz River basins. Quaternary International, 375: 72-83. doi:10.1016/j.quaint.2014.11.058

Franco, N.V., Martucci, M., Ambrústolo, P., Brook, G., Mancini, M.V. \& Cirigliano, N. 2010, Ocupaciones humanas correspondientes a la transición Pleistoceno-Holoceno al sur del macizo del deseado: el área de La Gruta (provincia de Santa Cruz, Argentina). Relaciones de la Sociedad Argentina de Antropología, 35: 301-308. (in Spanish) ("Human occupation corresponding to the Pleistocene-Holocene transition of southen Macizo del Deseado: the area of La Gruta (province of Santa Cruz, Argentina”)

Frank, A.D. 2011, Tratamiento térmico y manejo del fuego en sociedades cazadorasrecolectoras de la Meseta Central de Santa Cruz. Doctoral thesis at the Facultad de Ciencias Naturales y Museo, Universidad Nacional de La Plata, La Plata, 303 p. (in Spanish) ("Heat treatment and fire management in hunter-gatherer societies of the Meseta Central of Santa Cruz”)

Frank, A.D. 2016, Tratamiento térmico de artefactos líticos en Cerro Tres Tetas 1, meseta central de Santa Cruz, Patagonia Argentina. In: Arqueología de la Patagonia: De mar a mar (Mena, F., Ed.), Ediciones CIEP y Ñire Negro, Santiago de Chile: 367-378 p. (in Spanish) ("Heat treatment of lithic artifacts in Cerro Tres Tetas 1, Central Plateau of Santa Cruz, Patagonia Argentina ”)

Frank, A.D., Skarbun, F. \& Cueto, M.E. 2015, Tool production processes in lithic quarries from the Central Plateau of Santa Cruz, Argentina. Quaternary International, 375: 8498. doi:10.1016/j.quaint.2014.07.049

García-Herbst, A., Stern, C., Neff, H., Lanata, J.L. \& García Albarido, L. 2007, Laser Ablation ICP-MS Analysis of Black Obsidian Nodules from Pampa del Asador and Archaeological Samples from Southernmost Patagonia (Santa Cruz Province). In: Arqueología de Fuego - Patagonia. Levantando piedras, desenterrando huesos... y develando arcanos (Morello, F., Martinic, M., Prieto, A. \& Bahamonde, G., Eds.), Ediciones CEQUA, Punta Arenas: p. 235-246.

Gómez Otero, J. \& Stern, C. 2005, Circulación, intercambio y uso de obsidianas en la costa de la provincia del Chubut (Patagonia Argentina), durante el Holoceno tardío.

Intersecciones en antropología, 6: 93-108. (in Spanish) (“Circulation, exchange and use of obsidian on the coast of the province of Chubut (Patagonia Argentina), during the late Holocene”)

Hermo, D. 2008, Los cambios en la circulación de las materias primas líticas en ambientes mesetarios de Patagonia. Una aproximación para la construcción de los paisajes arqueológicos de las sociedades cazadoras-recolectoras. Doctoral thesis at the Facultad de Ciencias Naturales y Museo, Universidad Nacional de La Plata, La Plata, 463 p. (in Spanish) ("Changes in the circulation of lithic raw materials in Patagonia mesetarios environments. An approach to the construction of the archaeological landscape of the hunter-gatherer societies”) 
Hermo, D. \& Miotti, L. 2010, La obsidiana en el Nesocratón del Deseado (Santa Cruz, Argentina): extractos de una oscura biografía. In: Biografías de paisajes y seres. Visiones desde la arqueología sudamericana (Hermo, D. \& Miotti, L., Eds.), Encuentro Grupo Editor, Córdoba: p. 111-132. (in Spanish) (“Obsidian in the Deseado Massif (Santa Cruz, Argentina): extracts from an obscure biography”)

Iparraguirre, A. \& Cueto, M. (2015), Análisis de la tecnología lítica del Holoceno Medio en Cerro Tres Tetas, Cueva 1, Meseta Central de Santa Cruz, Argentina (oral presentation). Presented at the XIV Congreso Nacional de Estudiantes de Arqueología. Arqueologías y Redes, 23-25 de Septiembre, Córdoba. (in Spanish) (“Analysis of the lithic technology of the Middle Holocene in Cerro Tres Tetas, Cave 1, Central Plateau of Santa Cruz, Argentina”)

Miotti, L.L. 2006, Paisajes domésticos y sagrados desde la arqueología de los cazadoresrecolectores en el Macizo del Deseado, Provincia de Santa Cruz. Cazadores Recolectores del cono sur. Revista de Arqueología: 1: 11-40. (in Spanish) ("Domestic and sacred landscapes from archeology of hunter-gatherers in the Macizo de Deseado, Santa Cruz Province”)

Pallo, M.C. \& Borrero, L.A. 2015, ¿̇ntercambio o Movilidad?: Una Evaluación sobre el Uso de Escalas de Análisis Espaciales y Curvas de Declinación en Patagonia CentroMeridional (Argentina). Latin American Antiquity, 26(3): 287-303. (in Spanish) ("Exchange or mobility ?: An evaluation of the use of spatial scales and decline curve analysis in Central Southern Patagonia (Argentina)”) doi:10.7183/1045-6635.26.3.287

Panza, J.L. 1994, Descripción de la Hoja Geológica 4969-II. Tres Cerros Escala 1:250.000. Provincia de Santa Cruz. Boletin Vol. 213. Servicio Geológico Nacional, Buenos Aires. (in Spanish) ("Description of the Geological Map 4969-II. Tres Cerros Scale 1:250.000. Province of Santa Cruz”)

Paunero, R.S. 1994, El sitio Cueva 1 de la Localidad Arqueológica Cerro Tres Tetas (Ea San Rafael, Santa Cruz, Argentina). Anales de Arqueología y Etnología, 48-49: 73-90. (in Spanish) ("The Cueva 1 site of the archaeological site Cerro Tres Tetas (Ea San Rafael, Santa Cruz, Argentina”)

Paunero, R.S. 2000, Localidad Arqueológica La María. In: Guía de Campo de la Visita a las Localidades Arqueológicas: La Colonización del Sur de América Durante la Transición Pleistoceno/Holoceno (Miotti, L.L., Paunero, R.S., Salemme, M.C. \& Cattáneo, G.R., Eds.), Edición Nacional, La Plata, p. 101-127. (in Spanish) (“La María archaeological locality”)

Paunero, R.S. 2003, The Cerro Tres Tetas (C3T) locality in the Central Plateau of Santa Cruz, Argentina. In: Where the South Winds Blow: Ancient Evidence of Paleo South Americans (Miotti, L.L., Salemme, M.C., Flegenheimer, N. \& Bonnichsen, R., Eds.), Center for the Studies of the First Americans (CSFA) and Texas A \& M University Press, College Station: p. 133-140.

Paunero, R.S. \& Castro, A.S. 2001, Análisis lítico y funcionalidad del componente inferior de Sitio Cueva 1, Localidad Arqueológica Cerro Tres Tetas, Provincia de Santa Cruz, Argentina. Anales del Instituto de la Patagonia. Serie Ciencias Humanas, 29: 189-206. (in Spanish) ("Lithic analysis and functionality of the lower component of Cueva 1 site, archaeological locality Cerro Tres Tetas, Province of Santa Cruz, Argentina”) 
Paunero, R.S., Castro, A.S. \& Reyes, M. 2007a, Estudios Líticos del componente medio del sitio Cueva 1 de Cerro Tres Tetas, Santa Cruz, Argentina: Implicaciones para construir patrones de distribución artefactual y uso del microespacio. In: Arqueología de Fuego Patagonia. Levantando piedras, desenterrando huesos...y develando arcanos (Morello, F., Martinic, M., Prieto, A. \& Bahamonde, G., Eds.), Centro de Estudios del Cuaternario Antártico (CEQUA). Punta Arenas: p. 613-622. (in Spanish) ("Lithic studies of the medium component of the site Cueva 1 Cerro Tres Tetas, Santa Cruz, Argentina: Implications for patterns build of artifactual distribution and use of microespacio”)

Paunero, R.S., Frank, A.D., Cueto, M., Skarbun, F. \& Valiza Davis, C. 2015, La Ocupación Pleistocénica de Cueva Túnel, Meseta Central de Santa Cruz: un Espacio que Reúne Actividades en torno al Procesamiento Primario de Presas. Atek Na, 5: 149-188. (in Spanish) ("The Pleistocene occupation of Cueva Túnel, Central Plateau of Santa Cruz. A space which gathers activities related to the primary processing of prey”)

Paunero, R.S., Frank, A.D., De Feo, C., Lunazzi, N., Ramos, D. \& Valiza Davis, C. (2010), Sitios a cielo abierto en la Meseta Central de Santa Cruz: metodología y resultados en perspectiva regional (oral presentation). Presented at the XVII Congreso Nacional de Arqueologia Argentina, Mendoza. (in Spanish) (“Open sky sites in the Central Plateau of Santa Cruz: methodology and results in regional perspective”)

Paunero, R.S., Frank, A.D., Skarbun, F., Rosales, G., Cueto, M.E., Zapata, G., Paunero, M.F., Lunazzi, N. \& Del Giorgio, M. 2007b, Investigaciones Arqueológicas en Sitio Casa Del Minero 1, Estancia La María, Meseta Central de Santa Cruz. In: Arqueología de FuegoPatagonia. Levantando piedras, desenterrando huesos... y develando arcanos (Morello, F., Prieto, A., Martinic, M. \& Bahamonde, G., Eds.), Centro de Estudios del Cuaternario Antártico (CEQUA), Punta Arenas, Chile: p. 577-588. (in Spanish) (“Archaeological research at Casa Del Minero 1 site, Estancia La María, Central Plateau of Santa Cruz”)

Paunero, R.S., Frank, A.D., Skarbun, F., Rosales, G., Zapata, G., Cueto, M.E., Paunero, M.F., Martinez, D.G., López, R., Lunazzi, N. \& Del Giorgio, M. 2005, Arte Rupestre en Estancia La María, Meseta Central de Santa Cruz: Sectorización y contextos arqueológicos. Relaciones de la Sociedad Argentina de Antropología, 30: 147-168. (in Spanish) ("Rock Art in Estancia La Maria, Meseta Central of Santa Cruz: Sectorización and archaeological contexts”)

Paunero, R.S., Lunazzi, N., Valiza Davis, C., Del Giorgio, M., Paunero, M.F. \& Pifano, J. (2011), Estudio de sitios a cielo abierto en meseta y costa de Santa Cruz: La María y Península de San Julián (oral presentation). Presented at the VIII Jornadas de Arqueología de la Patagonia Malargüe. (in Español) (“Open heaven sites study in the plateau and coast of Santa Cruz: La María and San Julián Peninsula”)

Pelegrin, J. 2006, Long blade technology in the Old World: an experimental approach and some archaeological results. In: Skilled Production and Social Reproduction. Aspects of Traditional Stone-Tool Technologies (Apel, J. \& Knutsson, K., Eds.), Societas Archaeologica Upsaliensis, Uppsala: p. 37-68.

San Román, M. \& Prieto, A. 2004, (Dis)continuidad del uso de obsidiana verde entre poblaciones de adaptación marítima del mar de Otway y estrecho de Magallanes. In: Contra viento y marea: arqueología de Patagonia (Civalero, T., Fernández, P. \& Guráieb, G., Eds.), Instituto Nacional de Antropología y Pensamiento Latinoamericano (INAPL), Buenos Aires: p. 571-580. (in Spanish) (“(Dis)continuity of the green obsidian use among populations of maritime adaptation of Otway Sea and Strait of Magellan”) 
Skarbun, F. 2009, Análisis de los conjuntos líticos del sitio La Mesada, Localidad Arqueológica La María, Meseta Central de Santa Cruz. In: Arqueología de Patagonia: una mirada desde el último confín Vol. 2 (Salemme, M.C., Santiago, F., Álvarez, M., Piana, E., Vazquez, M. \& Mansur, M.E., Eds.), Editorial Utopías, Ushuaia: p. 11771194. (in Spanish) (“Analysis of the lithic assemblages of La Mesada site, La María Archaeological Locality, Central Plateau of Santa Cruz”)

Skarbun, F. 2011, La organización tecnológica en grupos cazadores recolectores desde las ocupaciones del Pleistoceno final al Holoceno tardío, en la Meseta Central de Santa Cruz, Patagonia. BAR International Series 2307. Archaeopress, Oxford, 213 p. (in Spanish) ("Technological organization of hunter gatherers from Final Pleistocene and Late Holocene occupations in the Central Plateau of Santa Cruz, Patagonia”)

Skarbun, F. 2015, Estructura y explotación de los recursos líticos en el sector Meridional de la Meseta Central de Santa Cruz, Argentina. Magallania, 43: 191-210. (in Spanish) ("Structure and exploitation of lithic resources of Meridional sector of Central Plateau of Santa Cruz, Argentina”)

Skarbun, F. \& Frank, A.D. 2011, Organización espacial intrasitio durante el Pleistoceno final en la Meseta Central de Santa Cruz. Evidencias del sitio Casa del Minero 1. Relaciones de la Sociedad Argentina de Antropología, 36: 289-313. (in Spanish) (“Intrasite spatial organization during the late Pleistocene in the Mesa Central of Santa Cruz. Site evidence Casa del Minero 1”)

Stern, C.R. 1999, Black obsidian from Central-South Patagonia: Chemical Characteristics, Sources and Regional Distribution of Artifacts. In: Soplando en el viento... Actas de las III Jornadas de Arqueología de Patagonia (Goñi, R., Ed.), Instituto Nacional de Antropología y Pensamiento Latinoamericano y Universidad Nacional del Comahue, Neuquén-Buenos Aires: p. 221-234.

Stern, C.R. \& Franco, N. 2000, Obsidiana gris verdosa veteada en la cuenca superior del río Santa Cruz, extremo sur de Patagonia. Anales del Instituto de la Patagonia, 28: 265273. (in Spanish) ("Grey-green banded obsidian in the upper basin of the Santa Cruz River, Southern tip of Patagonia”)

Stern, C.R., Prieto, A. \& Franco, N.V. 1995, Obsidiana negra en sitios arqueológicos de cazadores-recolectores terrestres en Patagonia austral. Anales del Instituto de la Patagonia (Ser. Cs. Hs.),23: 105-109. (in Spanish) ("Black obsidian in archaeological sites from land hunter gatherers in Southern Patagonia”)

Stern, C.R. \& Prieto, C. 1991, Obsidiana verde de los sitios arqueológicos en los alrededores del mar de Otway, Magallanes, Chile. Anales del Instituto de la Patagonia (20): 139144. (in Spanish) ("Green obsidian from the archaeological sites near the Otway Sea”)

Stern, R.C. 2004, Obsidian in Southern Patagonia: Review of the current information. In: Contra viento y marea. Arqueología de Patagonia (Civalero, P., Fernández, P. \& Guráieb, A.G., Eds.), Instituto Nacional de Antropología y Pensamiento Latinoamericano y Sociedad Argentina de Antropología, Buenos Aires: p. 167-176. 


\title{
La explotación de la obsidiana en la Meseta Central de Santa Cruz, Argentina. Resultados de La María y Cerro Tres Tetas en perspectiva regional
}

\author{
Manuel E. Cueto ${ }^{1}$, Ariel D. Frank ${ }^{2}$, Fabiana Skarbun ${ }^{3}$ \\ 1. Consejo Nacional de Investigaciones Científicas y Técnicas (CONICET), Argentina. \\ Email: manuelcueto@fcnym.unlp.edu.ar \\ 2. División Científica de Arqueología, Museo de Ciencias Naturales de La Plata, Argentina. \\ Email: frank.ariel@gmail.com \\ 3. Universidad Nacional de La Plata (UNLP). La Plata, Buenos Aires, Argentina. \\ Email: fskarbun@fcnym.unlp.edu.ar
}

\section{Resumen:}

Las localidades arqueológicas La María y Cerro Tres Tetas se ubican en la Meseta Central de Santa Cruz, Patagonia Argentina. El sector mencionado presenta abundancia de materias primas de muy buena calidad para la talla como sílex, calcedonia y xilópalo. Estas rocas fueron empleadas comúnmente por los habitantes de la región desde fines del Pleistoceno hasta momentos históricos recientes. Además, en los sitios arqueológicos hemos registrado la explotación de rocas alóctonas en menor proporción. Entre ellas, domina la obsidiana que proviene de fuentes situadas a más de $125 \mathrm{~km}$ de distancia. En este contexto, el uso de esta materia prima debe ser evaluado en términos de aspectos sociales y simbólicos.

En este artículo, examinamos las estrategias de abastecimiento y explotación de la obsidiana recuperada en los sitios Cerro Tres Tetas 1, Casa del Minero 1, Cueva de La Ventana, La Mesada y Cueva Túnel. En este sentido llevamos a cabo el análisis tecnomorfológico de los artefactos de obsidiana de estos sitios.

Los resultados alcanzados refuerzan la idea del conocimiento y explotación de la obsidiana de Pampa del Asador. Se ha registrado un aumento en la explotación de la obsidiana a través del tiempo, con un incremento importante hacia el Holoceno tardío. Se han identificado dos grandes momentos en la explotación de esta roca a nivel regional. Durante el Pleistoceno final y el Holoceno temprano, la obsidiana no habría jugado un rol relevante en la organización tecnológica. Por su parte las secuencias de producción se caracterizan probablemente por el ingreso a los sitios de los artefactos ya manufacturados. Durante el Holoceno medio y tardío se habrían ingresado nódulos y núcleos. Para este momento las estrategias involucradas en su manufactura concuerdan a grandes rasgos con las implementadas para las materias primas locales y no exponen elementos que permitan postular la mayor valorización de la obsidiana. Por otra parte tampoco es posible asociar la gestión de esta roca a una estrategia de explotación eventual. Consideramos que las sociedades habrían tenido acceso a la misma en el marco de circuitos de movilidad y contactos intergrupales.

Palabras clave: obsidiana; explotación; análisis tecnológico; Patagonia; Argentina 